\title{
Article \\ Cyclic Nigerosyl-Nigerose as Oxygen Nanocarrier to Protect Cellular Models from Hypoxia/Reoxygenation Injury: Implications from an In Vitro Model
}

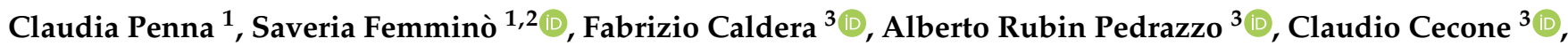 \\ Edoardo Alfì ${ }^{1}$, Stefano Comità ${ }^{1}$, Takanobu Higashiyama ${ }^{4}$, Francesco Trotta ${ }^{3, *}$, Pasquale Pagliaro ${ }^{1, *}$ (D) \\ and Roberta Cavalli ${ }^{5, *}$
}

\section{check for} updates

Citation: Penna, C.; Femminò, S.; Caldera, F.; Rubin Pedrazzo, A.; Cecone, C.; Alfi, E.; Comità, S.; Higashiyama, T.; Trotta, F.; Pagliaro, P.; et al. Cyclic Nigerosyl-Nigerose as Oxygen Nanocarrier to Protect Cellular Models from Hypoxia/Reoxygenation Injury: Implications from an In Vitro Model. Int. J. Mol. Sci. 2021, 22, 4208. https://doi.org/10.3390/ijms22084208

Academic Editor: Mihai V. Putz

Received: 10 March 2021

Accepted: 14 April 2021

Published: 19 April 2021

Publisher's Note: MDPI stays neutral with regard to jurisdictional claims in published maps and institutional affiliations.

Copyright: (C) 2021 by the authors. Licensee MDPI, Basel, Switzerland. This article is an open access article distributed under the terms and conditions of the Creative Commons Attribution (CC BY) license (https:/ / creativecommons.org/licenses/by/ $4.0 /)$.
1 Department of Clinical and Biological Sciences, University of Turin, 10043 Turin, Italy; claudia.penna@unito.it (C.P.); saveria.femmino@unito.it (S.F.); edoardo.alfi@unito.it (E.A.); stefano.comita@unito.it (S.C.)

2 Department of Medical Sciences, University of Turin, 10126 Turin, Italy

3 Department of Chemistry, University of Turin, 10125 Turin, Italy; fabrizio.caldera@unito.it (F.C.); alberto.rubinpedrazzo@unito.it (A.R.P.); claudio.cecone@unito.it (C.C.)

4 Hayashibara CO., LTD./Nagase Group 675-1 Fujisaki, Naka-ku, Okayama 702-8006, Japan; takanobu.higashiyama@hb.nagase.co.jp

5 Department of Drug Science and Technology, University of Turin, 10125 Turin, Italy

* Correspondence: francesco.trotta@unito.it (F.T.); pasquale.pagliaro@unito.it (P.P.); roberta.cavalli@unito.it (R.C.)

\begin{abstract}
Heart failure (HF) prevalence is increasing among the aging population, and the mortality rate remains unacceptably high despite improvements in therapy. Myocardial ischemia (MI) and, consequently, ischemia/reperfusion injury (IRI), are frequently the basis of HF development. Therefore, cardioprotective strategies to limit IRI are mandatory. Nanocarriers have been proposed as alternative therapy for cardiovascular disease. Controlled reoxygenation may be a promising strategy. Novel nanocarriers, such as cyclic nigerosyl-nigerose (CNN), can be innovative tools for oxygen delivery in a controlled manner. In this study we analyzed new $\mathrm{CNN}$-based formulations as oxygen nanocarriers $\left(\mathrm{O}_{2}-\mathrm{CNN}\right)$, and compared them with nitrogen $\mathrm{CNN}\left(\mathrm{N}_{2}-\mathrm{CNN}\right)$. These different CNN-based formulations were tested using two cellular models, namely, cardiomyoblasts (H9c2), and endothelial (HMEC) cell lines, at different concentrations. The effects on the growth curve during normoxia $\left(21 \% \mathrm{O}_{2}, 5 \% \mathrm{CO}_{2}\right.$ and $\left.74 \% \mathrm{~N}_{2}\right)$ and their protective effects during hypoxia $\left(1 \% \mathrm{O}_{2}\right.$, $5 \% \mathrm{CO}_{2}$ and $\left.94 \% \mathrm{~N}_{2}\right)$ and reoxygenation $\left(21 \% \mathrm{O}_{2}, 5 \% \mathrm{CO}_{2}\right.$ and $\left.74 \% \mathrm{~N}_{2}\right)$ were studied. Neither $\mathrm{O}_{2}-\mathrm{CNN}$ nor $\mathrm{N}_{2}-\mathrm{CNN}$ has any effect on the growth curve during normoxia. However, $\mathrm{O}_{2}-\mathrm{CNN}$ applied before hypoxia induces a 15-30\% reduction in cell mortality after hypoxia/re-oxygenation when compared to $\mathrm{N}_{2}-\mathrm{CNN}$. $\mathrm{O}_{2}-\mathrm{CNN}$ showed a marked efficacy in controlled oxygenation, which suggests an interesting potential for the future medical application of soluble nanocarrier systems for MI treatment.
\end{abstract}

Keywords: cyclic nigerosyl nigerose; oxygen delivery; myocardial infarction; ischemia; reperfusion

\section{Introduction}

The nanocarriers were studied for tissue-specific targeted delivery, triggered release, and co-delivery of synergistic drug combinations to develop new efficient therapeutics [1].

As a result of the high aerobic metabolism, the myocardium already exhibits a high extraction of oxygen in resting conditions compared to other muscle tissues. The heart is an organ with elevated consumption of oxygen in its basal condition, and under several different conditions, e.g., anemia, high altitude exposure, or vessel stenosis, cardiac oxygenation may become critical, leading to tissue hypoxia. In particular, during acute 
coronary occlusion, cardiac cell death occurs. This is the first phase of acute myocardial infarction (AMI) [2].

Complete and timely restoration of blood flow is mandatory in order to save the ischemic myocardium from irreversible ischemic injury; however, reperfusion induces additional injury, i.e., a reperfusion injury, and contributes to the final infarct size [3]. The lack of oxygen during ischemia and the subsequent re-introduction of oxygen during reperfusion, which lead to the massive formation of reactive oxygen species (ROS), are the basis of cardiac death and the inflammatory process, typical of ischemia/reperfusion injury. During AMI, a vicious cycle of deleterious events, including oxidative stress and inflammation, induces cardiac damage, impairing both diastolic and systolic function [2,4].

It is important to note the apparent paradox that ROS, which are normally considered lesion factors, at low concentrations and at the appropriate time of formation would induce myocardial protection [2,5-8]. Thus, the production of devices for the controlled delivery of oxygen can be of fundamental importance for reducing ROS lesions and favoring redoxinduced protection.

Protective strategies, such as slow re-flow procedures, have been proposed to limit re-oxygenation-induced lesions. However, this procedure has been abandoned, as it presents the problem of stagnant blood and consequent white blood cell infiltration [2,9]. Moreover, an intermittent re-flow (post-conditioning mode) has been suggested as an alternative strategy. Furthermore, intermittent reperfusion has raised several concerns in clinical settings, and full reperfusion is still the treatment of choice [10]. The ability of nanoparticles to aid in drug delivery by targeting regions affected by organ ischemia has been studied by many authors [11-14]. However, to the best of our knowledge, only one study has tested a polymer nanoparticle approach for delivering oxygen in a controlled manner to limit I/R injury [15].

Cyclic nigerosyl-nigerose (CNN) is an interesting and innovative nanocarrier for anticancer drug delivery in the cross-linked forms previously shown [16]. The major advantage of $\mathrm{CNN}$ is that its natural structure is a reservoir for oxygen.

$\mathrm{CNN}$ is a non-reducing cyclic tetrasaccharide with an unusual structure, consisting of four d-glucopyranosyl molecules connected by alternate $\alpha-(1-3)$ and $\alpha-(1-6)$ glycosidic bonds (Figure 1). The presence of two oxydryl groups oriented to the cavity of the molecules leads to a more hydrophilic polarity of the CNN cavity in comparison with the well-known cyclodextrin one. The smaller cavity is much more prone to hosting small molecules of suitable size and polarity.

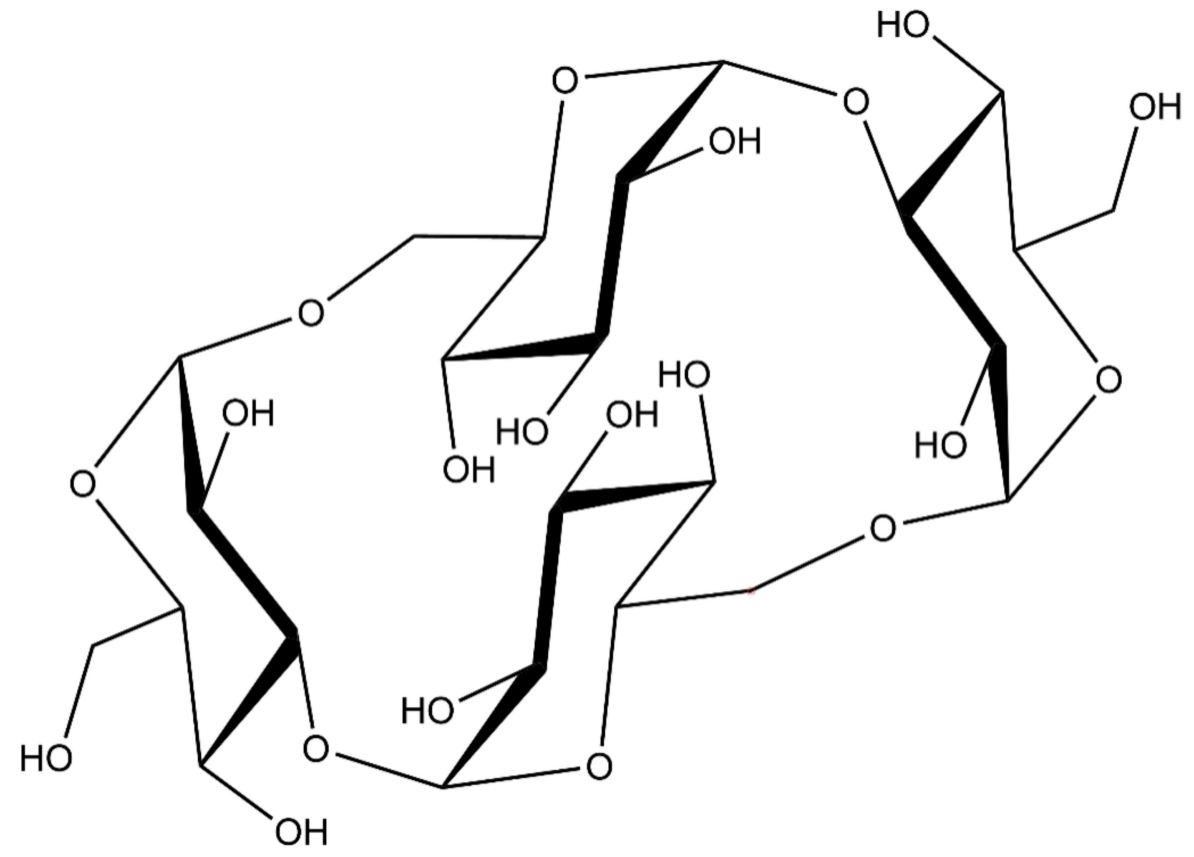

Figure 1. The structure of cyclic nigerosyl-nigerose (CNN). 
The objectives of this study are to evaluate oxygen release kinetics and to ascertain whether different concentrations of CNN loaded with oxygen - or with nitrogen as a control—can modulate cell growth and reduce cell mortality in a hypoxia/re-oxygenation $(\mathrm{H} / \mathrm{R})$ protocol when given before or after hypoxia, using two different cellular models.

\section{Results}

\subsection{In Vitro Oxygen Release Kinetics}

The $\mathrm{pH}$ value of cyclic nigerosyl-nigerose solution, either in the presence or in the absence of oxygen, was 6.0, and the osmolarity was about 300 mOsm. Hemolysis testing was performed (see CNN samples at all the concentrations tested), indicating good biocompatibility and a tonicity value suitable for the cell experiments. The in vitro oxygen release kinetics from $\mathrm{CNN}$ solution $(\mathrm{NaCl} 0.9 \% \mathrm{w} / \mathrm{v})$ in the two receiving phases, at $37^{\circ} \mathrm{C}$, are shown in Figure 2. As can be seen, $\mathrm{O}_{2}$ concentration reached a maximum level after $15 \mathrm{~h}$ both in saline solution and in a cell culture medium.

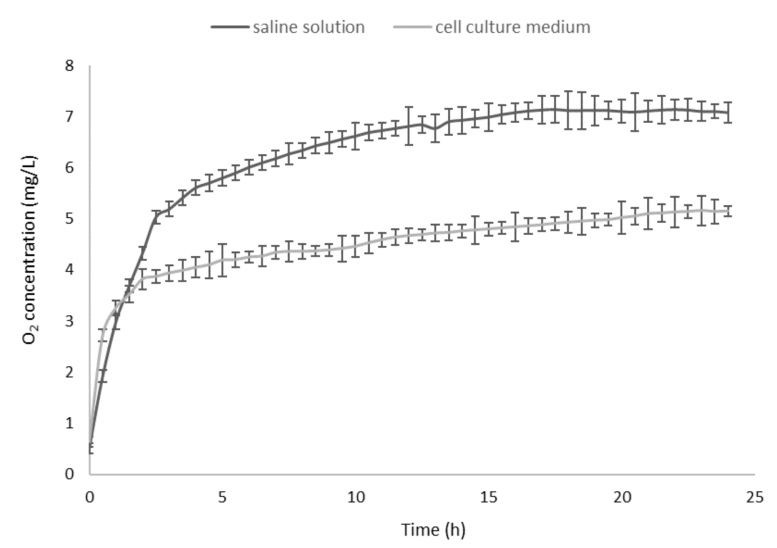

Figure 2. In vitro oxygen release kinetics from oxygen-loaded cyclic nigerosyl-nigerose solution $(\mathrm{NaCl} 0.9 \% w / v)$ in the two receiving phases ( $\mathrm{NaCl} 0.9 \% w / v$ and cell culture medium).

A sustained oxygen release was observed in both of the receiving phases, reaching an oxygen concentration of $7.08 \mathrm{mg} / \mathrm{L}$ and $5.15 \mathrm{mg} / \mathrm{L}$, in the saline solution and the cell culture medium, respectively.

The in vitro release profile of oxygen from the oxygen-loaded CNN glycerol solution containing dextran-70 $(6 \% w / v)$ was compared to that of a common plasma volume expander $(5 \% w / v$ glucose solution containing dextran-70 $(6 \% w / v))$ saturated with oxygen (Figure 3).

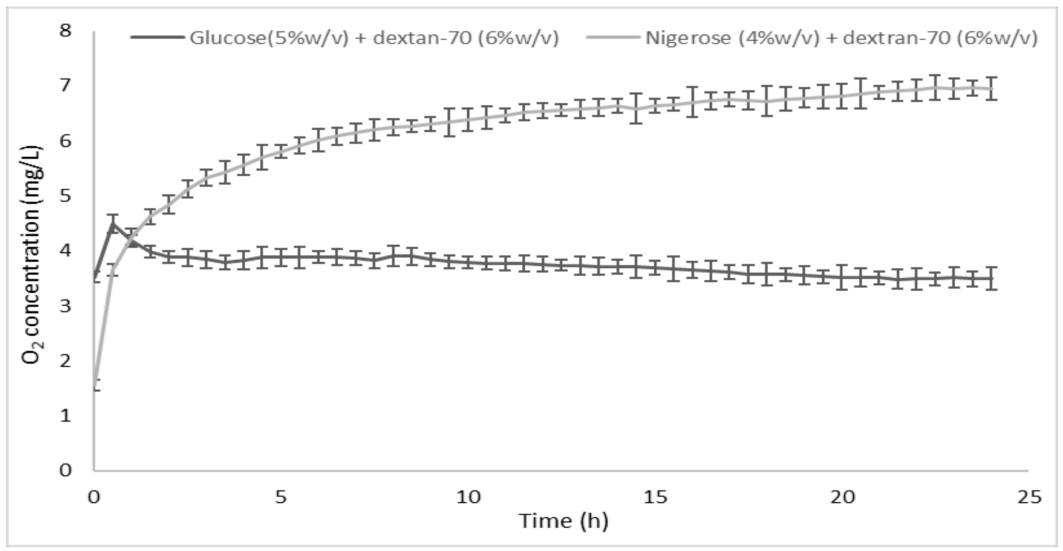

Figure 3. In vitro oxygen release kinetics from the oxygen-loaded cyclic nigerosyl-nigerose glycerol solution containing dextran-70 $(6 \% w / v)$, compared to a $5 \% w / v$ glucose solution containing dextran$70(6 \% w / v)$. 
The characteristics of the oxygen-loaded CNN samples are reported in Table 1.

Table 1. Characteristics of oxygen-loaded cyclic nigerosyl-nigerose samples.

\begin{tabular}{|c|c|c|c|}
\hline & $\begin{array}{l}\text { Cyclic Nigerosyl-Nigerose } \\
(4 \% \text { w/v) in } \mathrm{NaCl}(0.9 \% \text { w/v) }\end{array}$ & $\begin{array}{c}\text { Cyclic Nigerosyl-Nigerose } \\
(4 \% w / v) \text { in Glycerol }(2 \% w / v)+ \\
\text { Dextran-70 }(6 \% w / v)\end{array}$ & $\begin{array}{c}\text { Glucose }(5 \% w / v)+ \\
\text { Dextran-70 }(6 \% w / v)\end{array}$ \\
\hline $\mathrm{pH}$ & 6.00 & 6.05 & 5.85 \\
\hline Osmolarity (mOsm) & 310 & 300 & 280 \\
\hline Viscosity $(\mathrm{cP})$ & 1.07 & 2.30 & 3.05 \\
\hline
\end{tabular}

\subsection{Dose-Response and Growth Curve in Normoxic Conditions}

We report in Figure 4 results obtained with different concentrations $(0.2,2,10$, and $20 \mu \mathrm{g} / \mathrm{mL})$ of oxygenated $\left(\mathrm{O}_{2}-\mathrm{CNN}\right.$, upper panels) and non-oxygenated $\left(\mathrm{N}_{2}-\mathrm{CNN}\right.$, lower panels) nanocarriers, in normoxic conditions. The exposure of $\mathrm{H} 9 \mathrm{c} 2$ to different concentrations of CNN nanocarriers for 2 hours did not affect cell vitality, regardless of the presence of oxygen.

A)

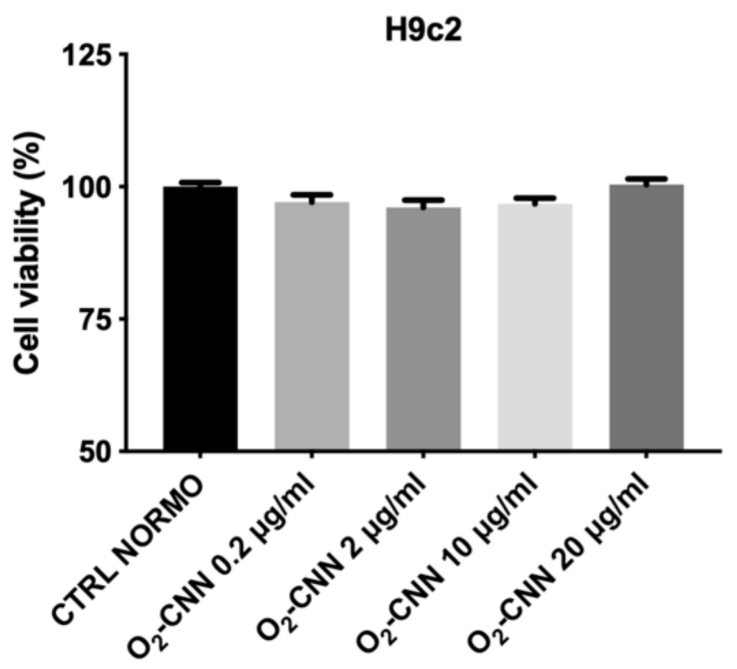

B)

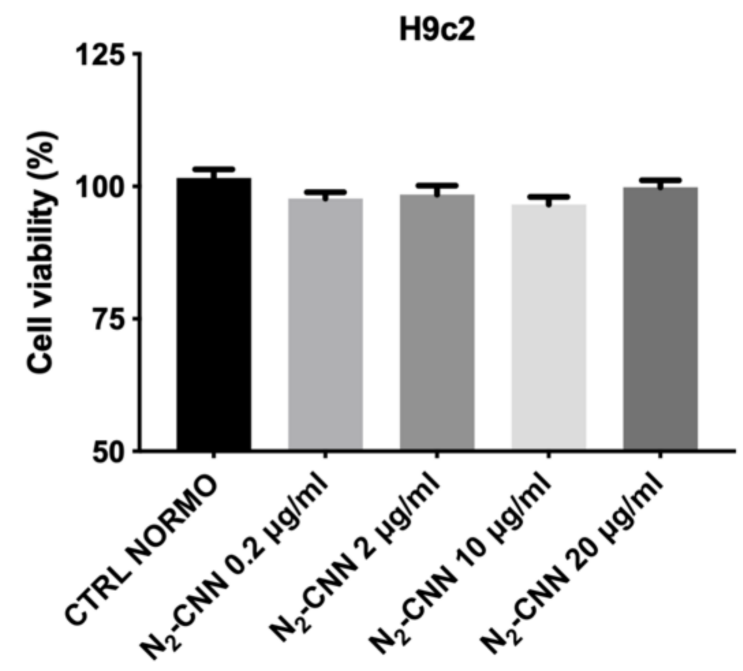

Figure 4. Dose-response of $\mathrm{H} 9 \mathrm{c} 2$ in normoxic conditions. (A): Treatment with $\mathrm{O}_{2}-\mathrm{CNN}(0.2,2,10$, and $20 \mu \mathrm{g} / \mathrm{mL}) \mathrm{compared}$ to the untreated control group (CTRL). (B): Treatment with $\mathrm{N}_{2}-\mathrm{CNN}(0.2,2,10$, and $20 \mu \mathrm{g} / \mathrm{mL})$ compared to the untreated control group (CTRL). Data were expressed as mean \pm SE. Data were normalized to the mean value under control conditions (CTRL NORMO) and expressed as a percentage.

To evaluate the effect of $\mathrm{CNN}$ on cellular growth, we have treated two different cell lines (H9c2 and HMEC) at a concentration of $10 \mu \mathrm{g} / \mathrm{mL}$, for varying periods of time (24, $48,72,96$, and $120 \mathrm{~h}$ ). Both the H9c2 and HMEC proliferations were unaffected by either $\mathrm{O}_{2}-\mathrm{CNN}$ or $\mathrm{N}_{2}-\mathrm{CNN}$ given for 5 days at $10 \mu \mathrm{g} / \mathrm{mL}$ (Figure $5 \mathrm{~A}, \mathrm{~B}$ ).

\subsection{Untreated Cells: Normoxic and $H / R$ Conditions}

Untreated (not exposed to CNN) H9c2 or HMEC cell lines were subjected to the H/R protocol, in order to evaluate their response to hypoxia and re-oxygenation. As can be seen in Figure $6 \mathrm{~A}, \mathrm{~B}$ the untreated H9c2 at the end of the H/R protocol (CTRL H/R) displayed a $47 \%$ reduction in vitality compared to the CTRL group. Indeed, cell vitality was $100 \pm 6 \%$ in CTRL and $63 \pm 10 \%$ in CTRL H/R ( $p<0.001$ CTRL vs. CTRL H/R). As can also be seen in Figure $6 \mathrm{C}, \mathrm{D}$ the untreated HMEC (not exposed to CNN) at the end of the H/R protocol (CTRL $\mathrm{H} / \mathrm{R}$ ) also displayed a $47 \%$ reduction in vitality compared to the CTRL group. Indeed, the cell vitality was $100 \pm 2 \%$ in CTRL and $63 \pm 1 \%$ in CTRL H/R ( $p<0.001$ CTRL vs. CTRL H/R). 
A)

\section{Growth curve H9c2}

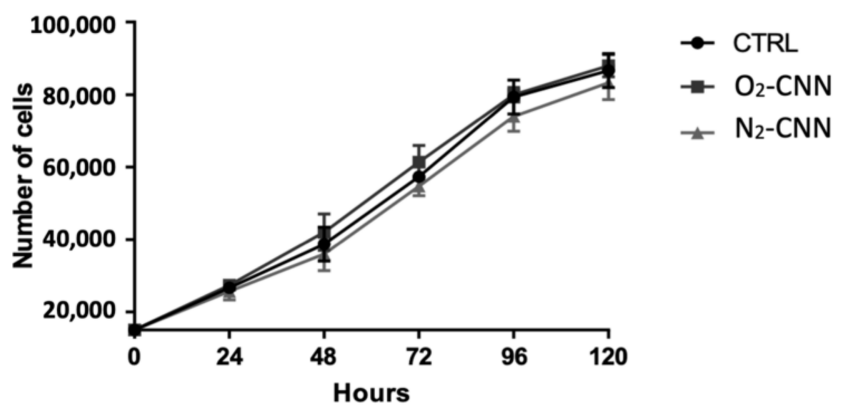

B)

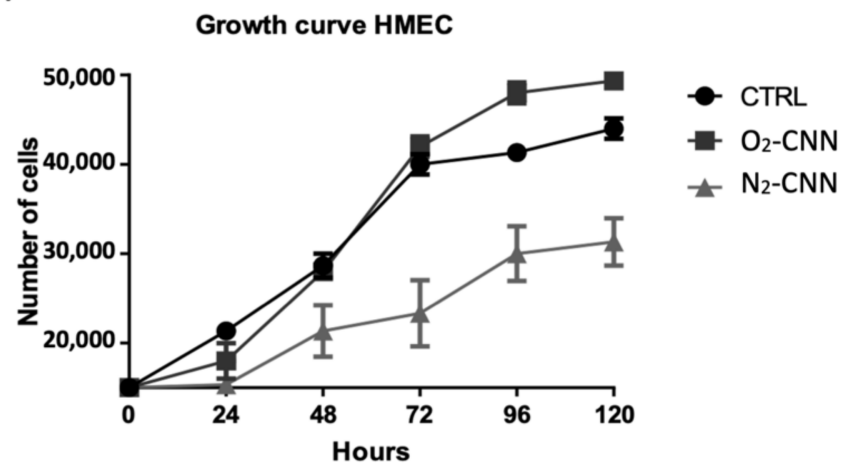

Figure 5. Growth curves of the two cell models. (A): Treatment of $\mathrm{H} 9 \mathrm{c} 2$ with $\mathrm{O}_{2}-\mathrm{CNN}$ or $\mathrm{N}_{2}-\mathrm{CNN}$ at $10 \mu \mathrm{g} / \mathrm{mL}$ compared to the untreated control group (CTRL). (B): Treatment of $\mathrm{HMEC}$ with $\mathrm{O}_{2}-\mathrm{CNN}$ or $\mathrm{N}_{2}-\mathrm{CNN}$ at $10 \mu \mathrm{g} / \mathrm{mL}$ compared to the untreated control group (CTRL). Data were expressed as mean $\pm \mathrm{SE}$.

A)

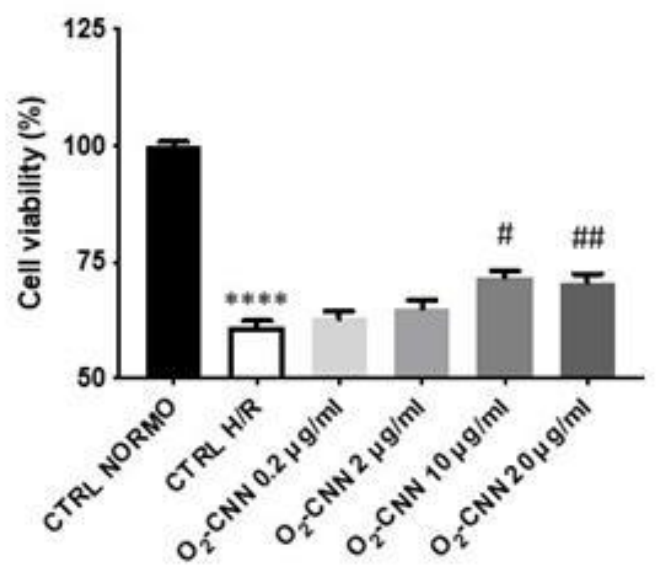

C)

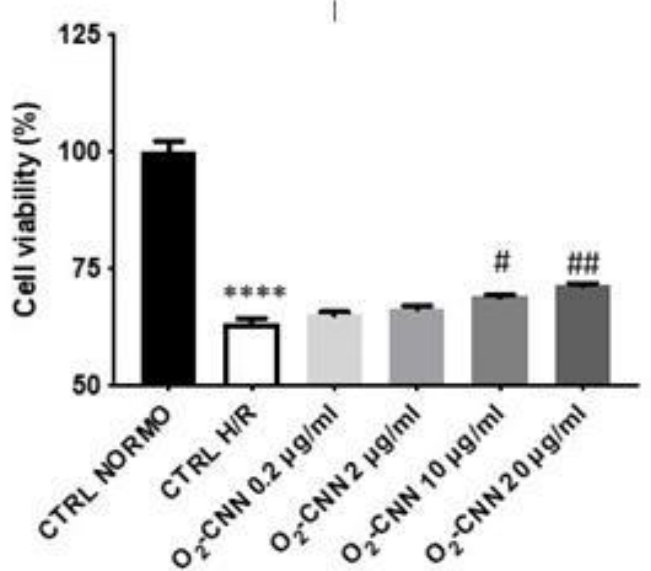

B)

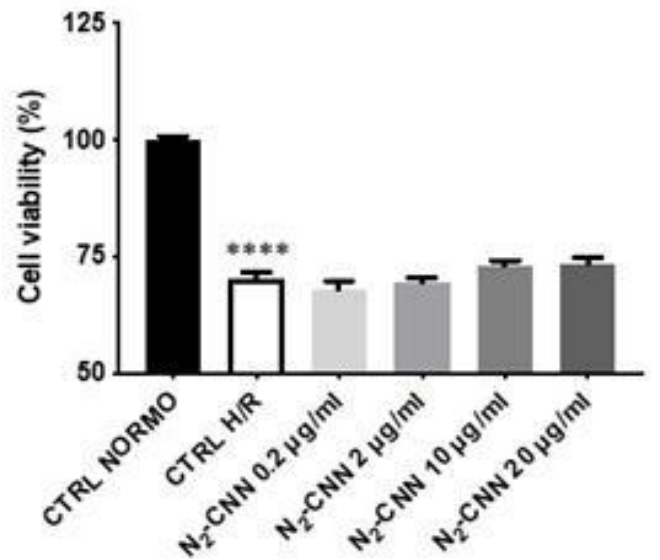

D)

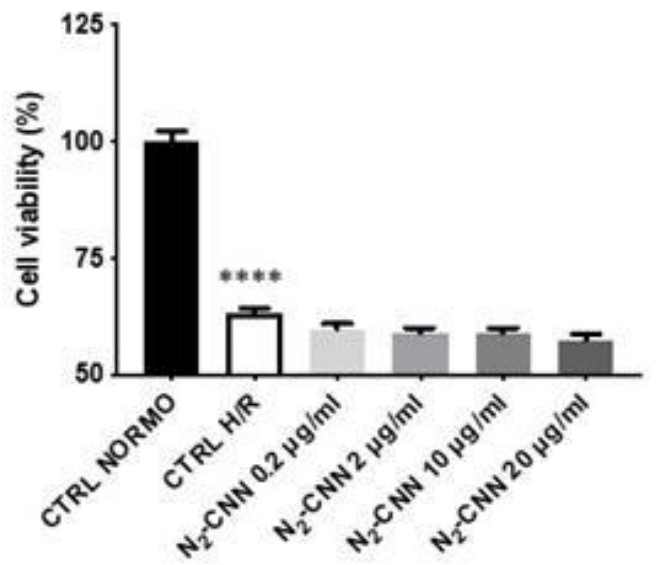

Figure 6. $\mathrm{CNN}$ pre-treated cells in $\mathrm{H} / \mathrm{R}$ conditions. (A,B): $\mathrm{O}_{2}-$ and $\mathrm{N}_{2}-\mathrm{CNN}$ pre-treated $\mathrm{H} 9 \mathrm{c} 2$ in $\mathrm{H} / \mathrm{R}$ conditions. (C,D): $\mathrm{O}_{2}$ - and $\mathrm{N}_{2}$-CNN pre-treated HMEC in H/R conditions. ${ }^{* * * *} p<0.0001$ vs. CTRL NORMO; ${ }^{*} p<0.01$ vs. CTRL H/R; \#\# $p<0.0001$ vs. CTRL H/R. Data were expressed as mean \pm SE. Data were normalized to the mean value in control conditions (CTRL NORMO) and expressed as a percentage.

\subsection{CNN-Pre-Treated Cells in $\mathrm{H} / \mathrm{R}$ Conditions}

In order to evaluate whether $\mathrm{O} 2-\mathrm{CNN}$ presents protective effects with respect to the $\mathrm{H} / \mathrm{R}$ protocol, we pre-treated both cell lines (H9c2 and HMEC) with increasing concentrations of the two formulations of $\mathrm{CNN}(0.2,2,10$, and $20 \mu \mathrm{g} / \mathrm{mL})$. Figure $6 \mathrm{~A}$, B shows 
that the $\mathrm{H} 9 \mathrm{c} 2$ cell line was protected only by $\mathrm{O}_{2}-\mathrm{CNN}$ pre-treatment at high concentrations of 10 and $20 \mu \mathrm{g} / \mathrm{mL}$ : at these concentrations, vitality was significantly higher than in CTRL H/R conditions ( $p<0.0001$ for both concentrations). $\mathrm{N}_{2}-\mathrm{CNN}$ was not protective at any concentration: vitality was not significantly higher than in CTRL H/R conditions. Figure 6C,D shows that similar results were obtained for HMEC. In fact, the HMEC cell line was also protected by $\mathrm{O}_{2}-\mathrm{CNN}$ pre-treatment at high concentrations of 10 and $20 \mu \mathrm{g} / \mathrm{mL}$ : vitality was significantly higher than CTRL H/R $(p<0.01$ and $p<0.0001$, respectively). $\mathrm{N}_{2}$-CNN was not protective at any tested concentration.

\subsection{CNN Post-Treated Cells in H/R Conditions}

At the end of the hypoxic period, both cell lines were treated with $\mathrm{O}_{2}$ or $\mathrm{N}_{2}-\mathrm{CNN}$ at increasing concentrations $(0.2,2,10$, or $20 \mu \mathrm{g} / \mathrm{mL})$. In Figure $7 \mathrm{~A}, \mathrm{~B}$, we show that the $\mathrm{H} 9 \mathrm{c} 2$ cell line was protected by $\mathrm{O}_{2}-\mathrm{CNN}$ post-treatment only at the highest concentration of $20 \mu \mathrm{g} / \mathrm{mL}$ : vitality was significantly higher than CTRL H/R $(p<0.0001)$. Meanwhile, $\mathrm{N}_{2}$-CNN was not protective at any tested concentration; in fact, the mortality was similar to that in CTRL H/R conditions. Surprisingly, post-treatment with $\mathrm{O}_{2}-\mathrm{CNN}$ in the HMEC cell line was not protective at any concentration used, as shown in Figure 7C,D.

A)

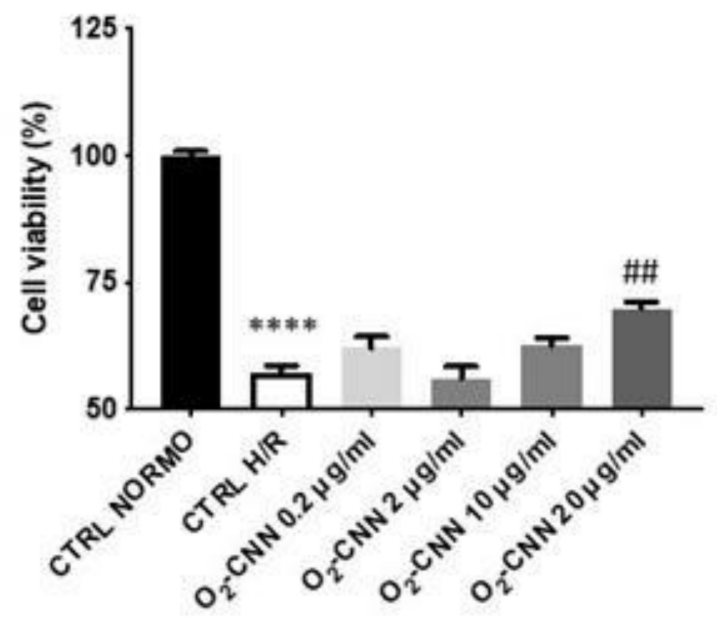

C)

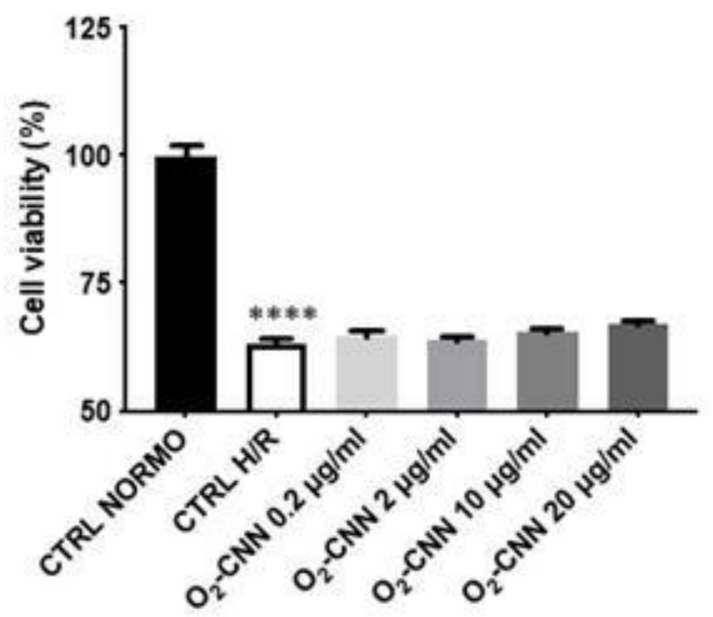

B)

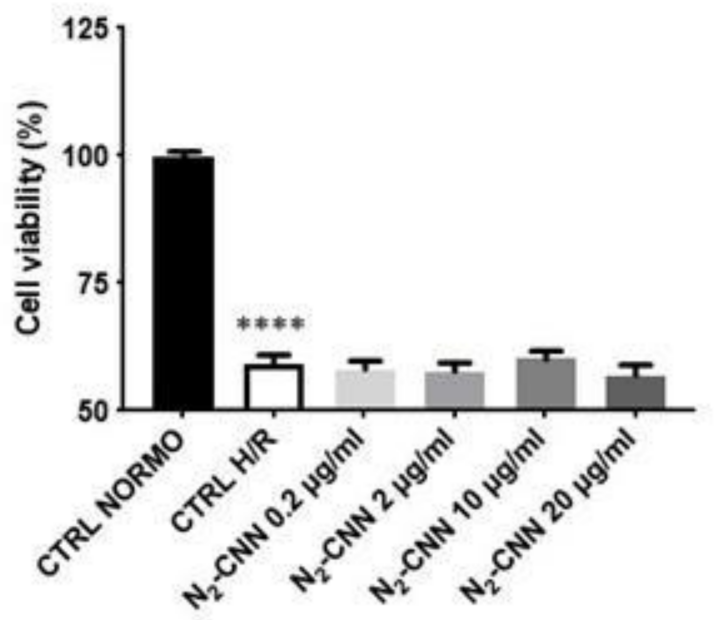

D)

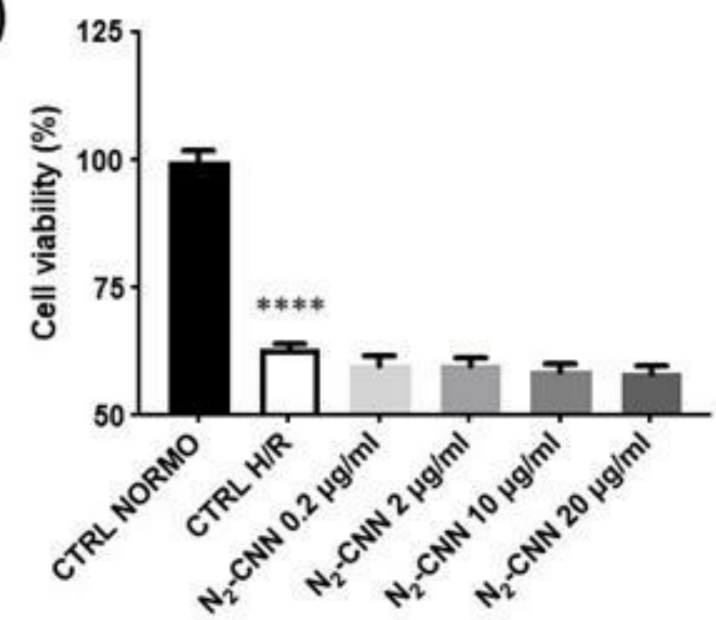

Figure 7. $\mathrm{CNN}$ post-treated cells in $\mathrm{H} / \mathrm{R}$ conditions. (A,B): $\mathrm{O}_{2}$ and $\mathrm{N}_{2} \mathrm{CNN}$ post-treated $\mathrm{H} 9 \mathrm{c} 2 \mathrm{in} \mathrm{H} / \mathrm{R}$ conditions. (C,D): $\mathrm{O}_{2}$ and $\mathrm{N}_{2} \mathrm{CNN}$ post-treated HMEC in H/R conditions. ${ }^{* * *} p<0.0001$ vs. CTRL NORMO; ${ }^{* \#} p<0.0001$ vs. CTRL H/R. Data were expressed as mean $\pm \mathrm{SE}$. Data were normalized to the mean value in control conditions (CTRL NORMO) and expressed as a percentage. 
To corroborate the MTT-based data in terms of cell death and hypoxia mechanisms in cardiomyoblasts (H9c2), we performed Western blot analyses of cleaved caspase- 3 and hypoxia-inducible factor 1-alpha (Hif-1 $\alpha$ ), respectively (Figure 8). These two assays were analyzed at $\mathrm{O}_{2}-\mathrm{CNN}$ concentrations that displayed protective results via MTT. Both assays displayed a trend in line with the results obtained via MTT. Indeed, Hif- $1 \alpha$ and cleaved caspase- 3 were both reduced by $\mathrm{O}_{2}-\mathrm{CNN}$ pre-treatment. However, in post-treatment, $\mathrm{O}_{2}$-CNN seemed less protective.

A)
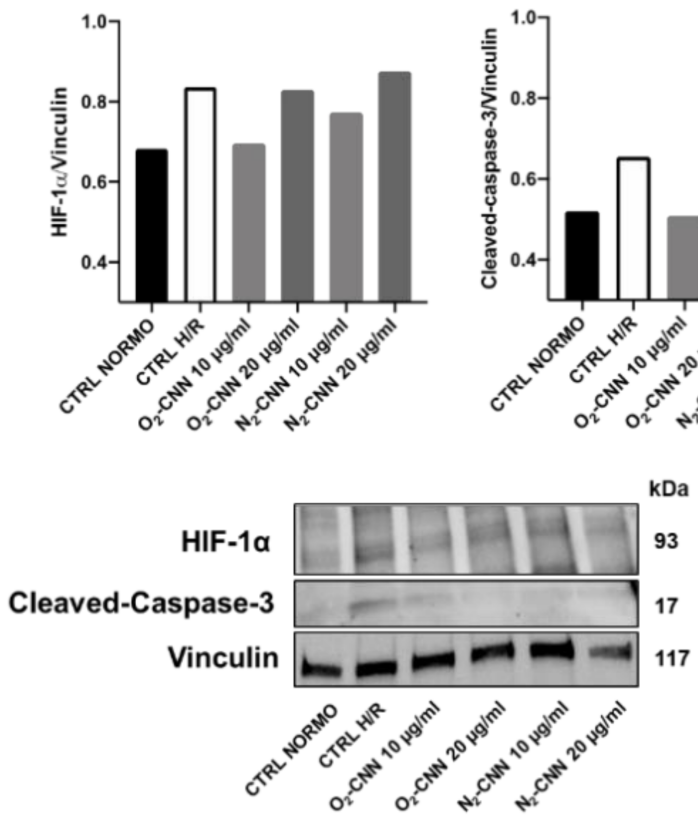

B)
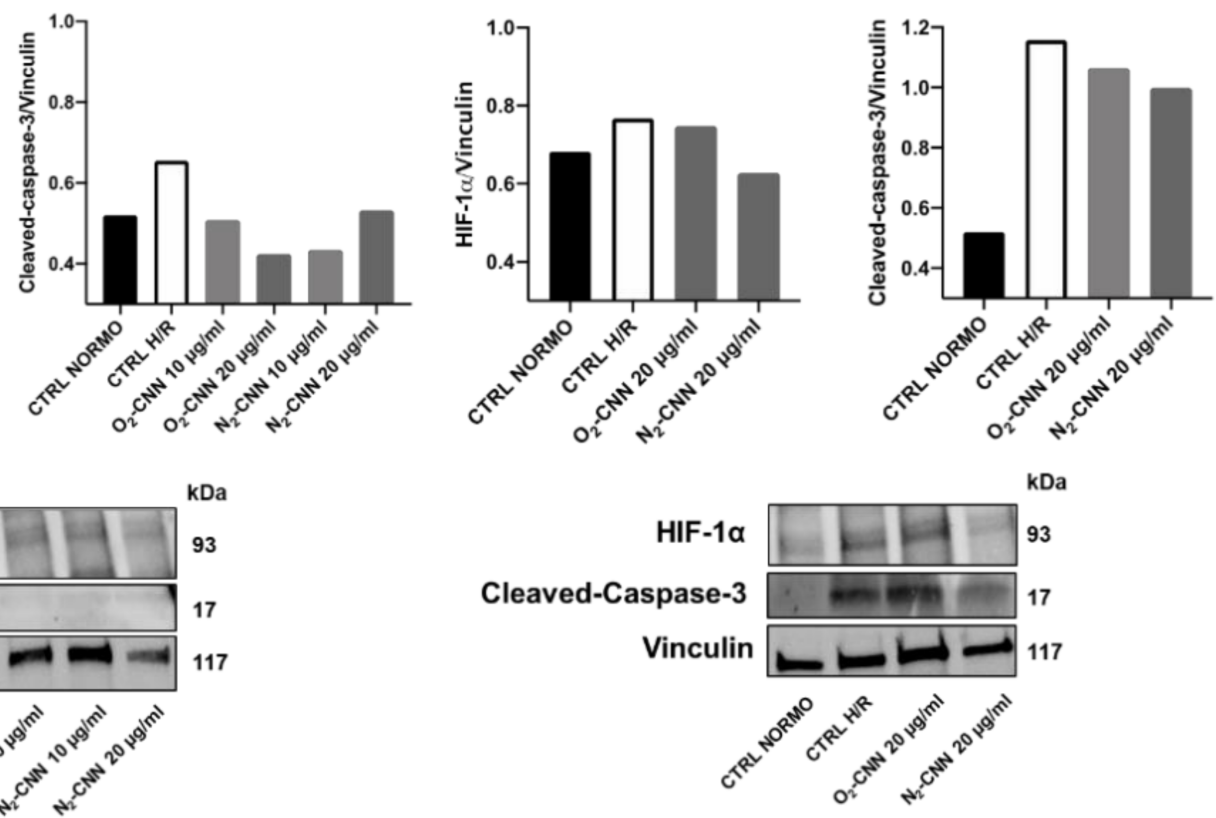

Figure 8. $\mathrm{O}_{2}$ and $\mathrm{N}_{2}-\mathrm{CNN}$ pre-treated $\mathrm{H} 9 \mathrm{c} 2$ in $\mathrm{H} / \mathrm{R}$ conditions. (A): $\mathrm{O}_{2}$ and $\mathrm{N}_{2}-\mathrm{CNN}$ post-treated $\mathrm{H} 9 \mathrm{c} 2$ in $\mathrm{H} / \mathrm{R}$ conditions. (B): Densitometric data and representative Western blots of HIF- $1 \alpha$, cleaved caspase-3, and vinculin (loading control).

\section{Discussion}

This study strongly indicates that oxygenated $\mathrm{CNN}$ is beneficial during an $\mathrm{H} / \mathrm{R}$ protocol, and limits cell death in two relevant cellular models (i.e., cardiomyocyte-like, $\mathrm{H} 9 \mathrm{c} 2$, and endothelial, HMEC) when applied before the hypoxic insult. When applied after hypoxia, at the beginning of re-oxygenation, its protective properties are limited to high concentrations, and in the $\mathrm{H} 9 \mathrm{c} 2$ model only. Moreover, our results demonstrate that neither $\mathrm{O}_{2}-\mathrm{CNN}$ nor $\mathrm{N}_{2}$-CNN has toxic effects, and they do not affect cell vitality or growth in normoxia, in two different cellular models. When given in the post-hypoxic phase, $\mathrm{O}_{2}-\mathrm{CNN}$ was protective only at high concentration, and only in one cellular model, underlining the different susceptibility to re-oxygenation injury of the cardiac and the endothelial cell lines.

Despite the success and recent improvement of interventional coronary reperfusion strategies, morbidity and mortality from AMI are still considerable. Myocardial infarct size is a major determinant of prognosis in heart failure patients. Myocardial ischemia/reperfusion elicits various types of cardiomyocyte death and coronary microvascular damage [17]. Therefore, cardioprotective strategies aimed at reducing infarct size that protect both cardiomyocytes and microvessels are much needed $[2,3,10,14]$. Here, the addition of nanocarriers charged with oxygen prior to hypoxia was protective for both cardiomyocyte-like (H9c2) and endothelial (HMEC) cell lines. When given after hypoxia, they were protective for H9c2 only, but were not damaging to HMEC. Future studies should focus first on clinically relevant animal models [18], and then on patients in severe need of adjunct cardioprotection. Hopefully, these oxygen formulations may be included in the clinical 
armamentarium, either in programmed intervention (programmed revascularization), or in acute ischemia/reperfusion (elective angioplasty in AMI), as they can provide protection either before or after an ischemic event. Importantly, they might protect both cardiomyocytes and microvessels, therefore boosting the potential for cardioprotection.

The release of oxygen has been the focus of extensive research, in particular for the reduction of cell death in hypoxic tissues [15,19-23]. The advantage of CNN is that the reduced size of the cavity allows it to host small molecules as gases. Recently, CNN in the form of a cross-linked polymer has been used, with excellent results, in the preparation of a new formulation of doxorubicin [16], a widely used anticancer drug.

The absence of oxygen, and its subsequent abrupt re-introduction, are considered the main mechanisms of ischemia/reperfusion injury. On one hand, the addition of this formulation - which releases oxygen slowly - before ischemia may represent a sort of pre-conditioning that triggers protection and builds a reservoir of oxygen that can support cell vitality during the absence of blood flow. On the other hand, the administration of this formulation immediately after ischemia may represent a sort of post-conditioning, protecting from reperfusion injury. The slow release of oxygen may limit reperfusion injury. Of note, while in pre-treatment both the 10 and $20 \mu \mathrm{g} / \mathrm{mL}$ concentrations were protective in both cell lines, only the higher concentration was protective in post-treatment, and in H9c2 only. Although we do not know the reasons for these differences, they open the possibility that endothelial cells are more sensitive to oxidative stress, and that different concentrations of $\mathrm{O}_{2}-\mathrm{CNN}$ formulation may be used in different clinical conditions. These results are interesting for the future use of $\mathrm{CNN}$ in clinical settings. The controlled release of oxygen could induce the activation of protective cascades, similar to conditioning, thus explaining their protective activity.

The ability to release oxygen would find numerous applications in the clinical setting, as well as at the cardiovascular level. One possible area could be the use of these oxygen carrier molecules as substitutes for hemoglobin. It is likely that, in patients with coronary disease, blood transfusion may in certain circumstances do more harm than good, even in anemic patients [24]. Therefore, substitutes for hemoglobin that overcome many of the problems associated with transfusion are much needed. Importantly, besides oxygen, the CNN may also deliver nitric oxide (NO), overcoming the putative impairment of NO effectiveness attributed to the transfused hemoglobin as well.

In conclusion, we have demonstrated here that oxygen-charged $\mathrm{CNN}$ has the potential to be beneficial in the context of hypoxia/re-oxygenation in vitro, limiting the cell damage in different cell lines and in a timing-specific manner. Whether $\mathrm{CNN}$ has beneficial effects in the context of ischemia/reperfusion in vivo remains to be ascertained. Future studies will determine the context in which these nanotools can be better exploited.

\section{Materials and Methods}

Cyclic nigerosyl-1,6-nigerose was a kind gift from HAYASHIBARA CO., LTD./NAGASE Group. All of the other chemical compounds were ACS grade and supplied by Sigma-Aldrich (St. Louis, MO, USA).

\subsection{Preparation and Characterization of Oxygen-Loaded Cyclic Nigerosyl-Nigerose Solution}

A weighted amount of cyclic nigerosyl-nigerose was dissolved in saline solution $(\mathrm{NaCl}$ $0.9 \% w / v)$ at a concentration of $40 \mathrm{mg} / \mathrm{mL}$. The $\mathrm{CNN}$ solution was then saturated with oxygen under an oxygen purge, until reaching an oxygen concentration of up to $35 \mathrm{mg} / \mathrm{L}$.

A second CNN sample was prepared by dissolving the $\mathrm{CNN}(40 \mathrm{mg} / \mathrm{mL})$ in a glycerol solution $(2 \% w / v)$ containing dextran-70 $(6 \% w / v)$. The sample was then saturated with oxygen, as previously described.

A glucose solution $(5 \% w / v)$ containing dextran-70 $(6 \% w / v)$ was used as a control, being a common plasma volume expander. This solution was saturated with oxygen.

The samples with or without oxygen were characterized in vitro by determining $\mathrm{pH}$ and tonicity. The $\mathrm{pH}$ was recorded at room temperature using an Orion $420 \mathrm{~A} \mathrm{pH}$ meter, 
while the osmolarity was measured using a Knauer K-7400 Semi-Micro Osmometer, also at room temperature. The viscosity of the samples was evaluated using a Ubbelohde capillary viscometer (Schott Gerate, Mainz, Germany).

\subsection{Hemolytic Activity Determination}

The hemolysis assay was performed to evaluate the biocompatibility of the nigerose sample.

For hemolytic activity determination, $100 \mu \mathrm{L}$ of $\mathrm{CNN}$ solution at different $\mathrm{CNN}$ concentrations was incubated with $1 \mathrm{~mL}$ of blood diluted with PBS ( $\mathrm{pH} 7.4,1: 4 v / v)$ at $37{ }^{\circ} \mathrm{C}$ for $90 \mathrm{~min}$. After incubation, the samples were centrifuged at $1000 \mathrm{rpm}$ for $5 \mathrm{~min}$ to separate the plasma. The amount of hemoglobin released due to hemolysis was determined spectrophotometrically (absorbance readout at $543 \mathrm{~nm}$ using a Beckman DU spectrophotometer). The hemolytic activity was calculated to compare with a negative control consisting of diluted blood without the addition of the samples. Complete hemolysis (positive control) was induced by the addition of ammonium sulphate $(20 \% w / v)$.

\subsection{In Vitro Oxygen Release Kinetics from Oxygen-Loaded Nigerose Solution}

In vitro oxygen release from the CNN solution was investigated using the dialysis bag technique. The donor phase, consisting of a $3 \mathrm{~mL}$ sample of oxygen-loaded CNN, was placed in a dialysis bag (Spectra/Por cellulose membrane, $12 \mathrm{kDa}$ ) Then, it was put in $45 \mathrm{~mL}$ of the receiving phase, consisting of saline solution $(\mathrm{NaCl} 0.9 \% w / v)$ or cell culture medium (DMEM), whose oxygen concentration was previously reduced (up to $1 \mathrm{mg} / \mathrm{L}$ ) with an $\mathrm{N}_{2}$ purge in order to mimic hypoxic conditions. The concentration of oxygen released from the CNN into the receiving phase was monitored for $24 \mathrm{~h}$, using an oximeter (Hach HQ40d).

The in vitro oxygen release kinetics were also evaluated at $37^{\circ} \mathrm{C}$, using cell culture medium as the receiving phase.

\subsection{Cellular Model}

Cardiomyoblast $(\mathrm{H} 9 \mathrm{c} 2)$ was obtained from the American Type Culture Collection (ATCC; Manassas, VA, USA). The medium nutrient mixture of modified Dulbecco F-12 Ham (DMEM) was used to grow the H9c2 samples, in addition to $10 \%$ fetal bovine serum (FBS) and 1\% $(v / v)$ streptomycin/penicillin (Wisent Inc., Quebec, QC, Canada), at $37{ }^{\circ} \mathrm{C}$ and $5 \% \mathrm{CO}_{2}[15,25,26]$.

Upon reaching $80 \%$ confluence the cells were detached from the flask, counted in the Burker chamber, and plated in 96-well plates with a density of 5000 cells/well. After $48 \mathrm{~h}$, the H9c2 samples were subjected to dose-response analysis, growth curve, or the hypoxia/re-oxygenation $(\mathrm{H} / \mathrm{R})$ protocols.

Human microvascular endothelial cells (HMEC) were obtained from the American Type Culture Collection. HMEC was grown in MCDB 131 Medium supplemented with $10 \%$ fetal bovine serum (FBS), $10 \mathrm{ng} / \mathrm{mL}$ of epidermal growth factor, $1 \mu \mathrm{g} / \mathrm{mL}$ of hydrocortisone, $2 \mathrm{mM}$ glutamine, and $1 \%(v / v)$ streptomycin/penicillin, at $37{ }^{\circ} \mathrm{C}$ and $5 \% \mathrm{CO}_{2}$ [27]. When the HMEC samples reached $80 \%$ confluence, they were seeded in 96 -well plates at 5000 / well and subjected to dose-response analysis, growth curve, or the H/R protocols.

\subsection{Protocols}

\subsubsection{Normoxic Experimental Conditions (Dose-Response Studies and Growth Curve)}

To verify the toxicity level of the oxygenated $\left(\mathrm{O}_{2}-\mathrm{CNN}\right)$ or non-oxygenated (nitrogen $\left(\mathrm{N}_{2}-\mathrm{CNN}\right)$ ) cyclic nigerosyl-nigerose nanosponges to either cellular model, the CNN-based formulations have been tested at different concentrations $(0.2,2,10$, and $20 \mu \mathrm{g} / \mathrm{mL})$.

Therefore, the cell viability of the untreated control groups (cells with F-12 Ham DMEM, only $2 \%$ bovine serum, CTRL) was analyzed. The latter was compared with the cell viability of cells exposed to the following formulations based on $\mathrm{O}_{2}-\mathrm{CNN}$ and $\mathrm{N}_{2}-\mathrm{CNN}$, in normoxic conditions $\left(21 \% \mathrm{O}_{2}, 5 \% \mathrm{CO}_{2}\right.$ and $\left.74 \% \mathrm{~N}_{2}\right)$ (Figure 9). The growth cell curve was determined only for concentrations of $10 \mu \mathrm{g} / \mathrm{mL}$ of $\mathrm{O}_{2}-\mathrm{CNN}$ or $\mathrm{N}_{2}-\mathrm{CNN}$, for different 
times (every $24 \mathrm{~h}$ for 5 days), by counting the number of cells present in the monolayer using a Burker chamber.

\section{A) Protocol Dose- Response: Normoxic conditions: $37^{\circ} \mathrm{C} ; 21 \% \mathrm{O}_{2} ; 5 \% \mathrm{CO}_{2}$}

\begin{tabular}{|c|c|}
$\begin{array}{l}\mathrm{O}_{2}-\mathrm{CNN} \text { or } \mathrm{N}_{2}-\mathrm{CNN} \text { in DMEM } \\
\text { HAM F-12 \%FBS (2 hrs) }\end{array}$ & DMEM HAM F-12 2\%FBS \\
\hline & MTT test $3 \mathrm{hrs}$ \\
\hline
\end{tabular}

\section{B) Hypoxic experimental conditions: $37^{\circ} \mathrm{C} ; 1 \% \mathrm{O}_{2} ; 5 \% \mathrm{CO}_{2}$}

\begin{tabular}{|c|c|c|}
\hline Hypoxia + IB & \multicolumn{2}{c}{ DMEM HAM F-12 2\%FBS Reoxygenation } \\
\hline $2 \mathrm{hrs}$ & $1 \mathrm{hr}$ & MTT test $3 \mathrm{hrs}$ \\
\hline
\end{tabular}

\section{C) Pre-treatment hypoxic experimental conditions: $37^{\circ} \mathrm{C} ; 1 \% \mathrm{O}_{2} ; 5 \% \mathrm{CO}_{2}$}

$\mathrm{O}_{2}-\mathrm{CNN}$ or $\mathrm{N}_{2}-\mathrm{CNN}$ Hypoxia + IB

\begin{tabular}{|l|l|l|}
\hline $2 \mathrm{hrs}$ & $1 \mathrm{hr}$ & MTT test $3 \mathrm{hrs}$ \\
\hline
\end{tabular}

D) Post-treatment Hypoxic experimental conditions: $37^{\circ} \mathrm{C} ; 1 \% \mathrm{O}_{2} ; 5 \% \mathrm{CO}_{2}$

\begin{tabular}{|c|c|c|}
\hline Hypoxia + IB & \multicolumn{2}{c|}{ O 2 -CNN or N2-CNN DMEM HAM F-12 2\%FBS $^{2 \mathrm{hrs}}$} \\
\hline 2 & $1 \mathrm{hr}$ & MTT test 3 hrs \\
\hline
\end{tabular}

Figure 9. Experimental protocols: (A-D) represent different experimental conditions. 3-(4,5dimethylthiazol-2-yl)-2,5-diphenyltetrazolium bromide (MTT) test. IB: ischemic buffer.

4.5.2. Experimental Conditions of Untreated, and Pre- and Post-Treated, Cells in Hypoxia/Reoxygenation

For in-vitro hypoxia/re-oxygenation (H/R) experiments, the HMEC or H9c2 cell lines were serum-starved (FBS $2 \%$ ) for $24 \mathrm{~h}$.

Pre-treatment: Cells were pre-treated with a CNN solution saturated with $\mathrm{O}_{2}$ or $\mathrm{N}_{2}$ at four different concentrations $(0.2,2,10$, or $20 \mu \mathrm{g} / \mathrm{mL})$ and exposed to hypoxia $\left(1 \% \mathrm{O}_{2}\right.$, $5 \% \mathrm{CO}_{2}$ and $94 \% \mathrm{~N}_{2}$ ) with an ischemic buffer (IB) containing (in $\mathrm{mM}$ ): $137 \mathrm{NaCl}, 12 \mathrm{KCl}$, $0.49 \mathrm{MgCl}_{2}, 0.9 \mathrm{CaCl}_{2}, 4 \mathrm{HEPES}$, and 20 sodium lactate ( $\mathrm{pH}$ 6.2), for $2 \mathrm{~h}$. At the end of the hypoxic period, the cells were subjected to re-oxygenation $\left(21 \% \mathrm{O}_{2}, 5 \% \mathrm{CO}_{2}\right.$ and $\left.74 \% \mathrm{~N}_{2}\right)$ for one hour [15].

Post-treatment: Cells were exposed to hypoxia $\left(1 \% \mathrm{O}_{2}, 5 \% \mathrm{CO}_{2}\right.$ and $\left.94 \% \mathrm{~N}_{2}\right)$ with an IB for $2 \mathrm{~h}$. At the end of the hypoxic period, the cells were treated with CNN saturated with $\mathrm{O}_{2}$ or $\mathrm{N}_{2}$ at four different concentrations $(0.2,2,10$, or $20 \mu \mathrm{g} / \mathrm{mL})$ and were subjected to reoxygenation $\left(21 \% \mathrm{O}_{2}, 5 \% \mathrm{CO}_{2}\right.$ and $\left.74 \% \mathrm{~N}_{2}\right)$ for one hour.

At the end of reoxygenation, the MTT test was used to assess cell viability.

\subsection{MTT Assay}

At the end of the $\mathrm{H} / \mathrm{R}$ protocol, cell viability was assessed using the 3-(4,5-Dimethylthiazol2-yl)-2,5-diphenyltetrazolium bromide (MTT) kit (10 $\mu \mathrm{L} /$ well, Sigma, St. Louis, MO, USA) as indicated by the manufactory protocol. Briefly, after $2 \mathrm{~h}$ incubation at $37^{\circ} \mathrm{C}$, dimethyl sulfoxide (DMSO, Sigma, St Louis, MO, USA) was added. The plates were read at $570 \mathrm{~nm}$ to obtain optical density values $[15,25,26]$. 


\subsection{Western Blot Analysis 346}

Briefly, cells were cultivated into 6-well plates $(1 \times 105$ cells/well $)$ and exposed to 10 and $20 \mu \mathrm{g} / \mathrm{mL}$ of $\mathrm{O}_{2}-\mathrm{CNN}$ or $\mathrm{N}_{2}-\mathrm{CNN}$ under normoxic or $\mathrm{H} / \mathrm{R}$ conditions as described in Figure 9. At the end of the protocol, each cell group was lysed using RIPA Lysis Buffer with proteinase and phosphatase inhibitors, and total proteins were collected for the Western blot detection. Twenty micrograms of total cell extract were separated by electrophoresis in reducing and denaturing polyacrylamide gels and transferred onto nitrocellulose membranes. After saturation with tris buffer $5 \%$ BSA, blot strips were incubated with primary antibodies. Anti-Hif-1 $\alpha$, anti-cleaved caspase-3 (1:1000; Abcam ab52181and Abcam ab51608, Milan, Italy), and anti-vinculin antibodies (1:1000; Sigma-Aldrich AB6039, Milan, Italy) were used as primary antibodies. The strips were incubated for $1 \mathrm{~h}$ at room temperature with the secondary antibodies (1:10,000; BioRad, Milan, Italy), and signals were detected using the chemiluminescent reagent LiteAblot (Euroclone, Milan, Italy). Chemidoc Touch Imaging System software (BioRad, Milan, Italy) was used for densitometric analysis [28].

\subsection{Statistical Analysis}

All values were expressed as mean \pm SEM and were analyzed using the variance analysis test (ANOVA), followed by the Bonferroni post hoc test and Student's $t$ test. A value in the $p<0.05$ range was considered statistically significant.

\section{Conclusions}

CNN has the potential to deliver oxygen, limiting cell damage and providing a benefit in the context of ischemia/reperfusion. The biological observations obtained during this first study demonstrate the ability of these carriers to release oxygen under hypoxic conditions. Future studies will determine the contexts in which these nanotools can be better exploited.

Author Contributions: S.F., F.C., E.A., A.R.P., C.C., T.H. and S.C. performed the experiments. S.C. and E.A. performed Western blot analyses. P.P. and C.P. analyzed the data and designed the experiments. R.C., P.P., C.P. and F.T. conceived the work and wrote the paper. All authors have read and agreed to the published version of the manuscript.

Funding: This work was supported by ex $60 \%$-MIUR for C.P. and P.P.

Institutional Review Board Statement: The Institutional Review Board did not require ethical approval since this study followed the standard procedure conducted according to the guidelines of the Declaration of Helsinki.

Informed Consent Statement: Not applicable.

Acknowledgments: We thank Matteo Sorge for support for Western blotting analysis.

Conflicts of Interest: The authors declare no conflict of interest.

$\begin{array}{ll}\text { Abbreviations } \\ \mathrm{HF} & \text { Heart failure } \\ \mathrm{MI} & \text { Myocardial ischemia } \\ \mathrm{IRI} & \text { Ischemia/reperfusion injury } \\ \mathrm{CNN} & \text { Cyclic nigerosyl-nigerose } \\ \mathrm{O}_{2}-\mathrm{CNN} & \text { Oxygen CNN } \\ \mathrm{N}_{2}-\mathrm{CNN} & \text { Nitrogen CNN } \\ \mathrm{H} 9 \mathrm{c} 2 & \text { Cardiomyoblast } \\ \mathrm{HMEC} & \text { Human microvascular endothelial cells } \\ \mathrm{H} / \mathrm{R} & \text { Hypoxia/reoxygenation } \\ \mathrm{MTT} & \text { 3-(4,5-dimethylthiazol-2-yl)-2,5-diphenyltetrazolium bromide } \\ \mathrm{IB} & \text { Ischemic buffer } \\ \text { ROS } & \text { Radical oxygen species } \\ \text { AMI } & \text { Acute myocardial infarction }\end{array}$




\section{References}

1. Su, S.; Kang, P.M. Recent Advances in Nanocarrier-Assisted Therapeutics Delivery Systems. Pharmaceutics 2020, 12, E837. [CrossRef] [PubMed]

2. Pagliaro, P.; Penna, C. Redox signaling and cardioprotection: Translatability and mechanism. Br. J. Pharmacol. 2015, 172, 1974-1995. [CrossRef] [PubMed]

3. Hausenloy, D.J.; Yellon, D.M. Ischaemic conditioning and reperfusion injury. Nat. Rev. Cardiol. 2016, 13, 193-209. [CrossRef] [PubMed]

4. Pagliaro, P.; Moro, F.; Tullio, F.; Perrelli, M.G.; Penna, C. Cardioprotective pathways during reperfusion: Focus on redox signaling and other modalities of cell signaling. Antioxid. Redox Signal. 2011, 14, 833-850. [CrossRef]

5. Tullio, F.; Angotti, C.; Perrelli, M.G.; Penna, C.; Pagliaro, P. Redox balance, and cardioprotection. Basic Res. Cardiol. 2013, $108,392$. [CrossRef]

6. Evans, C.W.; Iyer, K.S.; Hool, L.C. The potential for nanotechnology to improve delivery of therapy to the acute ischemic heart. Nanomedicine 2016, 11, 817-832. [CrossRef]

7. Penna, C.; Rastaldo, R.; Mancardi, D.; Raimondo, S.; Cappello, S.; Gattullo, D.; Losano, G.; Pagliaro, P. Post-conditioning induced cardioprotection requires signaling through a redox-sensitive mechanism, mitochondrial ATP-sensitive $\mathrm{K}+$ channel and protein kinase C activation. Basic Res. Cardiol. 2006, 101, 180-189. [CrossRef]

8. Tsutsumi, Y.M.; Yokoyama, T.; Horikawa, Y.; Roth, D.M.; Patel, H.H. Reactive oxygen species trigger ischemic and pharmacological postconditioning: In vivo and in vitro characterization. Life Sci. 2007, 81, 1223-1227. [CrossRef]

9. Vinten-Johansen, J.; Granfeldt, A.; Mykytenko, J.; Undyala, V.V.; Dong, Y.; Przyklenk, K. The multidimensional physiological responses to postconditioning. Antioxid. Redox Signal. 2011, 14, 791-810. [CrossRef]

10. Martins-Marques, T.; Hausenloy, D.J.; Sluijter, J.P.G.; Leybaert, L.; Girao, H. Intercellular Communication in the Heart: Therapeutic Opportunities for Cardiac Ischemia. Trends Mol. Med. 2020, 27, 248-262. [CrossRef]

11. Serviddio, G.; Bellanti, F.; Sastre, J.; Vendemiale, G.; Altomare, E. Targeting mitochondria: A new promising approach for the treatment of liver diseases. Curr. Med. Chem. 2010, 17, 2325-2337. [CrossRef]

12. Lakshmanan, R.; Ukani, G.; Rishi, M.T.; Maulik, N. Trimodal rescue of hind limb ischemia with growth factors, cells, and nanocarriers: Fundamentals to clinical trials. Can. J. Physiol. Pharmacol. 2017, 95, 1125-1140. [CrossRef]

13. Bar, A.; Cohen, S. Inducing Endogenous Cardiac Regeneration: Can Biomaterials Connect the Dots? Front. Bioeng. Biotechnol. 2020, 8, 126. [CrossRef]

14. Davidson, S.M.; Andreadou, I.; Barile, L.; Birnbaum, Y.; Cabrera-Fuentes, H.A.; Cohen, M.V.; Downey, J.M.; Girao, H.; Pagliaro, P.; Penna, C.; et al. Circulating blood cells and extracellular vesicles in acute cardioprotection. Cardiovasc. Res. 2019, 115, 1156-1166. [CrossRef]

15. Femminò, S.; Penna, C.; Bessone, F.; Caldera, F.; Dhakar, N.; Cau, D.; Pagliaro, P.; Cavalli, R.; Trotta, F. $\alpha$-Cyclodextrin and $\alpha$-Cyclodextrin Polymers as Oxygen Nanocarriers to Limit Hypoxia/Reoxygenation Injury: Implications from an In Vitro Model. Polymers 2018, 10, 211. [CrossRef]

16. Caldera, F.; Argenziano, M.; Trotta, F.; Dianzani, C.; Gigliotti, L.; Tannous, M.; Pastero, L.; Aquilano, D.; Nishimoto, T.; Higashiyama, T; et al. Cyclic nigerosyl-1,6-nigerose-based nanosponges: An innovative $\mathrm{pH}$ and time-controlled nanocarrier for improving cancer treatment. Carbohydr. Polym. 2018, 194, 111-121. [CrossRef]

17. Sezer, M.; van Royen, N.; Umman, B.; Bugra, Z.; Bulluck, H.; Hausenloy, D.J.; Umman, S. Coronary Microvascular Injury in Reperfused Acute Myocardial Infarction: A View from an Integrative Perspective. J. Am. Heart Assoc. 2018, 7, e009949. [CrossRef]

18. Bøtker, H.E.; Hausenloy, D.; Andreadou, I.; Antonucci, S.; Boengler, K.; Davidson, S.M.; Deshwal, S.; Devaux, Y.; Di Lisa, F.; Di Sante, M.; et al. Practical guidelines for rigor and reproducibility in preclinical and clinical studies on cardioprotection. Basic Res. Cardiol. 2018, 113, 39. [CrossRef]

19. Cavalli, R.; Akhter, A.K.; Bisazza, A.; Giustetto, P.; Trotta, F.; Vavia, P. Nanosponge formulations as oxygen delivery systems. Int J. Pharm. 2010, 402, 254-257. [CrossRef]

20. Cavalli, R.; Bisazza, A.; Giustetto, P.; Civra, A.; Lembo, D.; Trotta, G.; Guiot, C.; Trotta, M. Preparation and characterization of dextran nanobubbles for oxygen delivery. Int. J. Pharm. 2009, 381, 160-165. [CrossRef]

21. Cavalli, R.; Bisazza, A.; Rolfo, A.; Balbis, S.; Madonnaripa, D.; Caniggia, I.; Guiot, C. Ultrasound-mediated oxygen delivery from chitosan nanobubbles. Int. J. Pharm. 2009, 378, 215-217. [CrossRef] [PubMed]

22. Magnetto, C.; Prato, M.; Khadjavi, A.; Giribaldi, G.; Fenoglio, I.; Jose, J.; Gulino, G.R.; Cavallo, F.; Quaglino, E.; Benintende, E.; et al. Ultrasound-activated decafluoropentane-cored and chitosan-shelled nanodroplets for oxygen delivery to hypoxic cutaneous tissues. RCS Adv. 2014, 4, 38433-38441. [CrossRef]

23. Prato, M.; Magnetto, C.; Jose, J.; Khadjavi, A.; Cavallo, F.; Quaglino, E.; Panariti, A.; Rivolta, I.; Benintende, E.; Varetto, G.; et al. $2 \mathrm{H}, 3 \mathrm{H}$-decafluoropentane-based nanodroplets: New perspectives for oxygen delivery to hypoxic cutaneous tissues. PLoS ONE 2015, 10, e0119769. [CrossRef] [PubMed]

24. Doyle, B. There will be blood. JACC Cardiovasc. Interv. 2009, 2, 54-55. [CrossRef]

25. Tullio, F.; Penna, C.; Cabiale, K.; Femminò, S.; Galloni, M.; Pagliaro, P. Cardioprotective effects of calcitonin gene-related peptide in isolated rat heart and in H9c2 cells via redox signaling. Biomed. Pharmacother. 2017, 90, 194-202. [CrossRef]

26. Pasqua, T.; Tota, B.; Penna, C.; Corti, A.; Cerra, M.C.; Loh, Y.P.; Angelone, T. pGlu-serpinin protects the normotensive and hypertensive heart from ischemic injury. J. Endocrinol. 2015, 227, 167-178. [CrossRef] 
27. Basilico, N.; Mondani, M.; Parapini, S.; Speciale, L.; Ferrante, P.; Taramelli, D. Plasmodium falciparum parasitized red blood cells modulate the production of endothelin-1 by human endothelial cells. Minerva Med. 2004, 95, 153-158.

28. Penna, C.; Femminò, S.; Tapparo, M.; Lopatina, T.; Fladmark, K.E.; Ravera, F.; Comità, S.; Alloatti, G.; Giusti, I.; Dolo, V.; et al. The Inflammatory Cytokine IL-3 Hampers Cardioprotection Mediated by Endothelial Cell-Derived Extracellular Vesicles Possibly via Their Protein Cargo. Cells 2020, 10, 13. [CrossRef] 